\title{
JOURNAL.RU
}

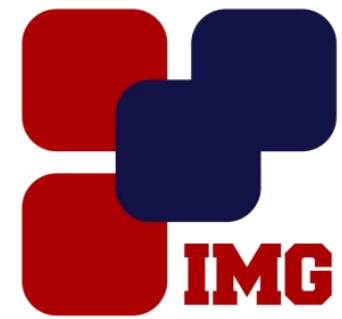

IVANoy
Management
GROUP

Мемишева Л.С., Бабанов Н.С. Научно-исследовательский институт сельского хозяйства Симферополь, Россия

doi: 10.18411/lj-31-05-2017-70

idsp 000001:lj-31-05-2017-70

\section{Новый высокопродуктивный сорт шалфея мускатного Орфей}

\section{Аннотация}

Создан новый сорт шалфея мускатного Орфей, отличающийся повышенным содержанием эфирного масла и склареола в сырье. Сорт имеет двухлетний цикл развития, среднеспелый, засухоустойчивый, характеризуется высокой семенной продуктивностью, пригоден к механизированной уборке.

Ключевые слова: шалфей мускатный, урожайность сырья, склареол , эфирное масло, сорт Орфей, первичное семеноводство.

\section{Abstract}

It was created the new Orpheus variety of salvia sclares. The variety had an increased content of essential oil and sclareol in raw materials, compared to other varieties of salvia. Orpheus has a two-year development cycle, it belongs to the middle ripe group of ripeness, drought-resistant and characterized by high seed productivity, also the variety is suitable for mechanized harvesting.

Keywords: salvia sclares, yield of raw material, sclareol, essential oil, variety Orphey, primary seed production.

Шалфей мускатный (Salvia sclarea L.) двулетнее растение семейства Яснотковые (Lamiaceae). В зависимости от биотипа и сорта растение образует в первый год вегетации розетку из листьев, а на второй год - стебель, цветонос, цветки и семена [1].

Шалфей мускатный возделывается для получения из его соцветий эфирного и экстрактового масел и других продуктов. Из свежих соцветий и 
отходов после паровой отгонки эфирного масла методом экстракции получают конкрет (экстракт), из которого в дальнейшее вырабатывают склареол, применяемый при изготовлении таких веществ, как амбриаль и амброксид. Склареол, обладающий антибактериальными свойствами, используют при изготовлении лечебных кремов и мазей [2].

Для изготовления продукции высшей парфюмерии необходимы стойкие фиксаторы запаха. В связи с тем, что поступление фиксаторов запаха животного происхождения (натуральной амбры и мускуса) значительно сократились, возник спрос, особо выросший в последние годы, на их заменитель растительного происхождения - дитерпеновый гликоль склареол, содержащийся в шалфее мускатном [3]. Таким образом, на все продукты переработки сырья шалфея мускатного уже длительное время сохраняются высокие оптовые цены, что приносит высокий доход их производителям [4].

До недавнего времени селекционная работа с шалфеем мускатным, главным образом, была ориентирована на создание высокопродуктивных сортов с высоким содержанием эфирного масла, с разными сроками созревания, устойчивых к абиотическим и биотическим факторам окружающей среды, пригодных к механизированной уборке сырья. Так как, ранее выведенные сорта не в полной мере отвечают современным требованиям рынка сбыта, заинтересованного не только в производстве шалфейного эфирного масла, но и других продуктов переработки, в настоящее время селекционные исследования направлены, прежде всего, на создание высокопродуктивных сортов шалфея мускатного с повышенным содержанием склареола в сырье [5].

Селекционерами Института эфиромасличных и лекарственных растений, вошедшего в состав ФГБУН «НИИСХ Крыма», в разные годы созданы многие сорта шалфея мускатного. Был создан, так называемый, конвейер сортов, различающихся по срокам достижения технической спелости, что снимало напряжение в период уборки и переработки сырья. В 2014 г. в «Государственный реестр селекционных достижений, допущенных к использованию» РФ вошло четыре сорта шалфея мускатного, оригинатором которых является ФГБУН «НИИСХ Крыма» [6]. В 2017 г. по решению ФГБУ «Госсорткомиссия» в Реестр включен новый сорт шалфея мускатного Орфей. В настоящей статье приведена информация о создании и характеристике нового сорта.

Селекционные исследования проводились в с. Крымская Роза, Белогорского района, Республика Крым в 2007-2010 гг. Территория относится к 
одному из пяти агроклиматических районов Крыма - четвёртому верхнему предгорному, теплому, недостаточно влажному, подрайон - северный с умеренно мягкой зимой [7]. Почва опытных участков - южный тяжелосуглинистый карбонатный чернозём, типичный для зоны и пригодный для выращивания шалфея мускатного ( $\mathrm{pH}-7,0-7,2$, содержание гумуса в пахотном слое $-2,7-3,0 \%$, общего азота $-0,12 \%$, общего фосфора $-0,1 \%$, калия $1,0 \%$, суммы поглощенных оснований - 27-32 мг-экв./100г абсолютно сухой почвы). Мощность гумусового горизонта достигает $35-60 \mathrm{~cm}$, окраска от, тёмносерого до, буровато - серого [8]. Сумма активных температур выше $10^{\circ} \mathrm{C}$ составляет $2800-3300^{\circ} \mathrm{C}$. Среднегодовая относительная влажность воздуха 72$73 \%$. В летние месяцы она снижается до 50-60\%, а в отдельные дни до $25-30 \%$, и ниже. Продолжительность безморозного периода в воздухе составляет 194 дня, на поверхности почвы - 167дней. Среднегодовая сумма осадков составляет 550мм. Гидротермический коэффициент в среднем равен 0,92 , что свидетельствует об умеренно-засушливом характере агроклиматических условий в период вегетации[10].

Исследования вели в соответствии с методическими рекомендациями, разработанными в Институте эфиромасличных и лекарственных растений [11]. Массовую долю склареола определяли экстракционно-хроматографическим методом, а массовую долю эфирного масла - методом гидродистилляции по Гинзбергу [3, 12]. Количественные данные, полученные в ходе исследований, обрабатывали с использованием общепринятых методов математической статистики [13].

Сорт шалфея мускатного Орфей получен путём индивидуального отбора из коллекционного образца среднеазиатского происхождения продуктивной формы с высоким содержанием склареола в сырье. Авторы сорта Л.Ф. Савченко и В.А. Чумак.

Сорт Орфей имеет двухлетний цикл развития с основным урожаем соцветий во второй год вегетации. Вегетационный период от отрастания розетки до технической спелости составляет 124 дня. Сорт среднеспелый, засухоустойчивый, обладает высокой семенной продуктивностью.

Высота растений шалфея мускатного сорта Орфей - 110-130 см, диаметр 47,5 см. Растение компактное, густооблиственное с хорошо развитыми 4-5 соцветиями. Стебель прямостоячий, среднеопушенный, диаметром 1,2-1,5 см. Листья продолговато-овальные, зелёные, среднеопушённые, морщинистые; расположение на стебле супротивное, прикорневая розетка листьев 
приподнятая. Стеблевые листья длиной 17 см и шириной 14 см, розеточные соответственно 22 и 19 см. Соцветие, ложная кисть, крупное, длиной до 52 см. Окраска венчика цветка светло-сиреневая, прицветники сиреневые. Семена (орешки) мелкие, округлой формы, тёмно коричневые. Масса 1000 семян - 4,5г. Эфирное масло хорошего парфюмерного качества (4,5 балла). Растения неполегающие, пригодные к механизированной уборке. Количество цветущих растений в первый год вегетации составляет 5\%, на второй год вегетации $-100 \%$.

Показатели продуктивности оценивали в питомнике конкурсного сортоиспытания в 2008-2010 гг. (табл.1).

НСР05 по урожайности соцветий: в 2008 г. - 10,7; 2009 г. - 8,5; 2010 г. 11,7 .

В качестве контроля использован сорт С-785. Анализ полученных данных за 2008-2010 гг. показал, что сорт шалфея мускатного Орфей превышает контроль по урожайности сырья на 11,9 ц/га, по сбору эфирного масла в 1,4 раза, по массовой доле склареола на абс. сухое вещество в 1,7 раза.

Сорт Орфей отличается от контроля более высокой засухоустойчивостью, оценка которой составляет 3,5 балла (C-785-3,0 балла). В годы испытаний болезней и вредителей не отмечено. Наблюдения в последующие годы показали, что сорт Орфей повреждается чёрной корневой гнилью на 19,5\%, а сорт С 785 на $29,4 \%$.

Таблий 1.

Показатели продуктивности сорта шалфея мускатного Орфей. Питомник КСИ, 2008-2010 г2.

\begin{tabular}{|l|c|c|c|c|c|c|c|c|}
\hline \multicolumn{1}{|c|}{ Показатели } & \multicolumn{4}{|c|}{ Сорт Орфей } & \multicolumn{4}{c|}{ Сорт С 785 (контроль) } \\
\cline { 2 - 10 } & 2008 & 2009 & 2010 & среднее & 2008 & 2009 & 2010 & среднее \\
\hline $\begin{array}{l}\text { Урожайность } \\
\text { сырья, ц/га }\end{array}$ & 133,6 & 157,5 & 208,7 & 166,7 & 121,5 & 152,2 & 190,6 & 154,8 \\
\hline $\begin{array}{l}\text { МДЭМ*, на } \\
\text { сырую массу на }\end{array}$ & 0,38 & 0,40 & 0,35 & 0,38 & 0,35 & 0,25 & 0,25 & 0,28 \\
\hline $\begin{array}{l}\text { МДЭМ* на абс. } \\
\text { сухое вещество, \% }\end{array}$ & 1,666 & 1,750 & 1,361 & 1,593 & 1,256 & 1,001 & 0,978 & 1,078 \\
\hline $\begin{array}{l}\text { Сбор эфирного } \\
\text { масла, кгга }\end{array}$ & 50,1 & 63,0 & 73,0 & 62,5 & 42,5 & 38,1 & 47,7 & 43,8 \\
\hline $\begin{array}{l}\text { МД**склареола, } \\
\text { \% на сырую массу }\end{array}$ & 1,0 & 0,92 & 0,60 & 0,84 & 0,78 & 0,60 & 0,48 & 0,62 \\
\hline $\begin{array}{l}\text { МД** склареола, } \\
\text { \% на абсолютно } \\
\text { сухую массу }\end{array}$ & 5,2 & 4,1 & 3,6 & 4,3 & 2,2 & 3,7 & 1,5 & 2,5 \\
\hline
\end{tabular}

Примечание: *МДЭМ -массовая доля эфирного масла, МД-массовая доля

Создание и внесение сорта в Реестр обязывает собственника и оригинатора поддерживать заявленные параметры весь период его эксплуатации. Задача первичного семеноводства шалфея состоит в том, чтобы обеспечить выращивание в достаточном количестве качественных 
оригинальных семян, необходимых для создания резерва и посевов суперэлиты и элиты.

Первичное семеноводство шалфея сорта Орфей осуществляется по стандартной для шалфея мускатного схеме, включающей массовую оценку растений в питомнике размножения ПР1, выбраковку нетипичных по морфологическим признакам [11].

Выращивание семян высоких посевных качеств возможно только при правильном ведении семеноводства. Под семенные посевы надо отводить поля наиболее плодородные и чистые от сорняков, не подверженные ветровой эрозии, и на которых он не высевался в течение 5-6 лет, лучшие предшественники озимые.

Питомники размножения ПР1 и ПР2 закладывают типичными чистосортными семенами урожая предыдущего года. Рекомендован подзимний посев в оптимальные для культуры сроки. Способ сева широкорядный с шириной междурядий 60-70см, норма высева семян 8-10кг/га, глубина заделки 3-4см. Маточники размещают изолированно от других посевов шалфея на расстоянии не менее 500 м. Уход за растениями осуществляется в полном объеме в течение первого и второго года вегетации. Используется стандартная для шалфея мускатного технология возделывания и переработки. В первый год вегетации удаляют все зацветшие растения «выскочки», а также больные и нетипичные для данного сорта кусты. На второй год вегетации до цветения вновь выбраковывают все нехарактерные растения. В период массового цветения с целью сохранения однородности сорта проводят апробацию. Удаляют все нетипичные для сорта растения: рано - и поздноцветущие формы, растения с фиолетовым, голубым и белым венчиком цветка, а также больные и сильно повреждённые вредителями.

К уборке приступают при созревании 60-70\% семян в соцветиях. Семена очищают от вороха и сушат. На сортировочно - очистительных машинах доводят их до посевных кондиций. При влажности семян не более $13 \%$ их затаривают в мешки, снабжают наружной и внутренней этикетками, указывают название сорта и категорию семян. Хранят в штабелях в сухих и хорошо проветриваемых зернохранилищах. Полученные в питомниках размножения ПР1-2 оригинальные семена предназначаются для посева с целью получения элитных семян.

Таким образом, создан новый высокопродуктивный сорт шалфея мускатного Орфей, отличающийся повышенным содержанием эфирного масла и 
склареола в сырье. Также сделан вывод, что для поддержания высоких показателей сорта необходимо методически правильное ведение первичного семеноводства.

1. Ксендз А.Г. Шалфей мускатный.-В кн.: Эфироносы Крыма.- Симферополь, »Крым». 1965. C.12-16.

2. Назаренко Л.Г., Афонин А.В Эфироносы юга Украины - Симферополь. Таврия, 2008. $144 \mathrm{c}$.

3. Гольдина В.Г., Шляпникова А.П., Сальникова Т.С. Хроматографический метод определения склареола //Основные направления научных исследований по интенсификации эфиромасличного производства. Ч.2.- Симферополь, 1985.- С.136.

4. Бабанов, Н.C. «Изучение селекционных образцов шалфея мускатного(Salvia sclarea L.) как исходного материала для создания нового сорта»/ Н.С.Бабанов, Л.С. Мемишева// Тенденции развития науки и образования. Сборник научных трудов, по материалам XVII международной научно-практической конференции 31 августа 2016 г. Часть 2.Самара.-2016 .-НИЦ «Л-Журнал». - С. 5-8. SPLN 001-000001-0046-82 Электронный режим доступа http://journal.ru

5. Савченко Л.Ф. Новый сорт шалфея мускатного/ Л.И. Савченко, В.А. Чумак. [электронный ресурс].режим доступа: http://po-teme.com.ua/rastenievosdstvo/stati-porastenievodcheskim-temam/1442-novyj-sort-shalfeya-muskatnogo-tajgan-i-egosemenovodstvo.html (дата обращения 03.03.2017).

6. Государственный реестр селекционных достижений, допущенных к использованию. Т 1. «Сорта растений» (официальное издание). М.: ФГБНУ Росинфобрмагротех», 2017. $504 \mathrm{c}$

7. Агроклиматический справочник по Крымской области. - Л.: Гидрометеоиздат, 1959. $136 \mathrm{c}$.

8. Половицкий И. Я.,Гусев П. Г. Почвы Крыма и повышение их плодородия. Симферополь: изд-во Таврия , 1987г. -152с.

9. Савчук, Л. П. Климат предгорья Крыма и эфироносы / Л. П. Савчук. - Симферополь, 2006. $-76 \mathrm{c}$.

10. Савчук Л.П., Касьянова Б. И. Агрометеорологическая характеристика территории ЦОПХ ВНИИЭМК /Тр. ВНИИЭМК - Симферополь, 1982.-Т.14.-С.142-148.

11. Селекция эфиромасличных культур: методические указания /[под.ред. А. И. Аринштейн]. - Симферополь, 1977.- 151.

12. Биохимические методы анализа эфирномасличных растений иэфирных масел // Сб. научн. трудов. - Симферополь-1972.-С.35-43.

13. Доспехов Б.А. Методика полевого опыта (с основами статистической обработки результатов исследований). - М.: Агропромиздат, 1985 - 352с. 